\title{
A New Era of Biometrics Applications
}

\author{
Kshitij Shinghal \\ Department of Electronics \& Communication, MIT Moradabad, India
}

Submission: January 23, 2018; Published: September 14, 2018

*Corresponding author: Kshitij Shinghal, Associate Professor, Department of Electronics \& Communication, MIT Moradabad, Uttar Pradesh, India; Email: kshinghal@gmail.com

\section{Opinion}

It is my pleasure to write this editorial for Biostatistics and Biometrics Open Access Journal (BBOAJ). Biometric is an emerging field involving calculations and measurements of physical or behavioral characteristics of human being. At present biometrics find its major application in identification and access control using any form of biometric measurement. Biometric identification and access control can be done on the basis of acquiring and matching the pre-stored data related to physical features of a person such as face recognition, fingerprint recognition, palm scans, recognition based on DNA, pulse rate, body temperature, palm shape and geometry, iris recognition, retina scan, retina color and body odor/scent or on the basis of behavior of a person such as his voice modulation and intonations, his body gait, his manner of doing certain task etc. Earlier biometrics found applications in access control for devices like computers, smartphones, laptops, attendance monitoring, surveillance etc. But in near future there will be a plethora of biometric applications for example if security is involved then using biometric system will make the operations and transactions more secure and reliable. Some of the future applications of biometrics are:

\section{Surveillance}

In the public places where crowd management is required, entry on the basis of biometric system will organize the system and will also help in recognition of fugitives, missing Childs, crowd and disaster management during events. However, deploying biometric systems at such a large scale may be a costly affair and its management and maintenance may become a complex issue.

\section{Duplicate Identification Checking}

Biometric based identity check might be performed to detect fraud, such as in the case where an individual has enrolled multiple times in a social benefits program.

\section{Biometric Based Vehicle Ignition and Entry Systems}

Biometric systems can be easily implemented for keyless vehicle entry and it can also be useful in protection against theft and identification in case of accidents.

\section{Automated Goods Dispensing Kiosks}

Such kiosks may dispense things automatically and charge will be deducted on the basis of biometric identification.

\section{Biometric Locks}

These locks can be used without any hassle of carrying keys or having any concern of losing keys again.

\section{Banking and Finance}

All transactions and banking may be done on the basis of combination of two or more biometric characteristics to make it more safe and secure. This will drastically reduce the number of financial or banking frauds and make the transactions more safe, secure and reliable.

\section{Biometric Intelligence Analysis and Tests}

Biometrics-based intelligence test can be performed on the basis of behavioral and physical analysis.

\section{Maintaining Records}

Biometric based record keeping systems can be deployed for keeping records of the most valuable personal documents or the documents which needs to be accessed quickly, accurately and timely without the hassle of going through exhaustive search processes.

\section{Other Biometric Applications}

Such as border security control, point of sale (POS) applications, attendance monitoring systems, smartcards etc., the list can go on endlessly. There is a vast scope of research and innovations in this fast-emerging field.

Biostatistics and Biometrics Open Access Journal (BBOAJ) is an International, Peer reviewed Journal of advanced technological developments based on advances in wo major areas that are concerned with the application of Statistics which deals with the proper interpretation of scientific data generated in the biology, public health and other health sciences like biomedical sciences and other major area of focus is Biometrics which deals with the measurable biological characteristics. In computer security, biometrics refers to authentication techniques that rely on measurable physical characteristics that can be automatically checked. BBOAJ aims to publish all Original articles using mathematics to enhance science and bridge the gap between theory and practice from the Biostatisticians. The journal solicits research papers for its forthcoming issue in all aspects of biostatistics and 
biometrics including fundamental understandings of diverse applications of biostatistics and biometrics. Journal accepts Research Papers, Review Articles, Short Communications, Case Reports, Mini-Reviews, Opinions, Letter to Editors, etc. in this field which will be enlightening the scientific community.

On behalf of the editorial team of the journal I invite authors from all over the world to share their innovative research and findings. Further I assure that the contents submitted to BBOAJ will enjoy more visibility and will be peer reviewed too. You can submit your works on any topic of your expertise with in the scope of journal. Journal ensures to share only high-quality content, so there is no room for copied or doubtful content to be published. The content should be unique, original and the presentation must be of potential interest to the readers. So once again I beseech timely submission of research papers for prospective publication in upcoming issue of the journal.

Email: biostats@juniperpublishers.com, biostats@juniperpublishers.org, biostats@juniperpublishers.us

\section{References and Acknowledgements}

I have based this paper on the materials collected from several courses I've attended. Some of this information is also featured in various tutorials available online. In addition, I have also consulted several web pages while writing this article. I would also like to thank Mr. Amit Saxena and Ms. Deepti Shinghal for their valuable support, without their help this article would have been impossible to complete.

\section{Your next submission with Juniper Publishers will reach you the below assets}

- Quality Editorial service

- Swift Peer Review

- Reprints availability

- E-prints Service

- Manuscript Podcast for convenient understanding

- Global attainment for your research

- Manuscript accessibility in different formats ( Pdf, E-pub, Full Text, Audio)

- Unceasing customer service

Track the below URL for one-step submission https://juniperpublishers.com/online-submission.php 